\title{
THE PRESENCE OF NATURAL HYDROCORTISONE IN SYNOVIAL FLUID
}

\author{
BY \\ C. L. COPE AND C. E. SEWELL \\ From the Postgraduate Medical School of London
}

(RECEIVED FOR PUBLICATION JULY 14, 1955)

\begin{abstract}
Although the profound therapeutic effects of cortisone and similar steroids were first revealed by their action on rheumatoid joints, there is still very little knowledge of the behaviour of these steroids in joints or in tissues. It is, for example, possible that difficulties of access of blood-borne hydrocortisone to the joint cavity may be a factor in the pathogenesis of rheumatoid arthritis or other joint diseases. However, scarcely anything is yet known about the diffusion of hydrocortisone into joint spaces. We have therefore attempted to obtain some preliminary information on these matters by estimating the hydrocortisone content of samples of synovial fluid obtained from knee joints affected by rheumatoid arthritis or similar conditions.
\end{abstract}

\section{Methods}

Extraction.-To minimize possible destruction of the hydrocortisone in the joint fluid after its removal from the joint, extraction is effected as promptly as possible. The samples of synovial fluid are shaken hard with at least three volumes of ethyl acetate in a separating funnel. The supernatant solvent is poured off and the residue extracted a second, and sometimes a third time, with a further three volumes of ethyl acetate which is added to the first supernatant. If smaller volumes of solvent are used, troublesome gel formation may occur, which is not adequately resolved by centrifuging. Such trouble is reduced by using large volumes of extracting solvent. Hard and prolonged shaking is desirable to ensure optimal extraction from such a viscous fluid. The ethyl acetate is evaporated to dryness under reduced pressure at a temperature below $50^{\circ} \mathrm{C}$. The residue is dissolved in acetone, one or two drops of a saturated solution of magnesium chloride in ethanol are added, and the flask is stood overnight in the cold room at $4^{\circ} \mathrm{C}$. Any phospholipids present are precipitated and these are filtered off. The acetone is evaporated to dryness. The residue in the flask is dissolved in about $50 \mathrm{ml}$. petroleum ether and extracted with four portions of $50 \mathrm{ml} .70 \mathrm{per}$ cent. aqueous methanol, which is also used to wash out any further residue from the flask. The methanol is distilled off from the separated aqueous methanol layer under reduced pressure, and the steroid is extracted from the remaining water by shaking four times with $25-\mathrm{ml}$. samples of chloroform. This chloroform is then evaporated to dryness, the residue being transferred finally to the bottom of a 10-ml. conical centrifuge tube.

Purification.-The residue is dissolved in a small을 volume (about $50 \mu \mathrm{l}$.) of a $1: 1$ chloroform-methanolmixture, and the whole is quantitatively transferred with a micro-pipette to the starting point of a paper chromatogram. Two lanes are run, one consisting of the synovial $\stackrel{\oplus}{7}$ fluid extract, the other of a standard sample of $20 \mu \mathrm{g}$. authentic hydrocortisone (free alcohol). The papers should be of such a width that the steroid does not $\vec{\omega}$ spread to the sides of the strip during developmen; ज a width of $4 \mathrm{~cm}$. per spot is usually sufficient. The system of Burton, Zaffaroni, and Keutmann (1951) used, in which propylene glycol is the stationary phase and toluene the mobile phase. Development is continued for 3 days. The chromatogram is then removed from the tank and dried thoroughly in a stream of warmळ air or with radiant heat. It is important that the propylene glycol be removed as completely as possible, andō at least 12 hours drying is desirable. The dry chromato- $\exists$ gram is then examined under ultraviolet light, whereby the reference hydrocortisone spot is revealed by its? opacity and a similar opacity may sometimes be detectedo in the synovial fluid extract. Ultraviolet opaque spotsō are outlined in pencil.

Recognition of Hydrocortisone.-The dry chromato-i gram is now developed by dipping rapidly through the blue tetrazolium reagent (see below) and then drying in a stream of warm air. In these conditions spots wheres reducing steroids such as hydrocortisone are present wills be revealed as bluish-violet zones where the reagent has? been reduced to a coloured formazan. Excess reagent is then removed by washing the paper in running tap-water ${ }^{\circ}$ for one hour and then drying. The coloured formazan is quite insoluble in water and no loss occurs during the washing. The hydrocortisone spot is then recognized ${ }^{\omega}$ by:

(a) its reduction of the tetrazolium reagent;

(b) its opacity to ultraviolet light;

(c) a rate of flow on the chromatogram the same as? authentic hydrocortisone. 
Estimation of Hydrocortisone.-A rectangle of known area is carefully marked out in pencil to contain the hydrocortisone spot, and an equal area of paper is marked out in the region free of reducing steroid immediately below the hydrocortisone zone to serve as a reagent blank. The standard hydrocortisone spot and its appropriate blank area are similarly marked out. All four rectangles of paper are cut out with scissors, cut into small pieces, and placed in ordinary test tubes. The blue pigment is then dissolved by adding $4 \mathrm{ml}$. acid pyridine to each tube (see below) and shaking occasionally. The pigment readily dissolves, but at least one hour should be allowed for complete elution. The colour intensity of the eluate is then read in any suitable colorimeter at a wavelength of $520 \mathrm{~m} \mu$. The zone representing the known amount of authentic hydrocortisone, similarly eluted, serves as a standard of colour for the estimation. Under these conditions the intensity of colour is proportional to the amount of hydrocortisone present over a range from 2 to $100 \mu \mathrm{g}$. per spot. In trial estimations of varying amounts of hydrocortisone, a standard deviation of about 15 per cent. was obtained by this method. But with quantities of steroid below about $5 \mu \mathrm{g}$. per spot, the accuracy of the estimation diminishes rapidly.

When small amounts of hydrocortisone are added to large volumes of human body fluids, the amount of the added steroid recovered by this technique is about 70 per cent. of the whole (Cope, Hurlock, and Sewell, 1955). It may be presumed therefore that in such fluids the true hydrocortisone content will be about 1.4 times the amount actually found.

The efficiency of the method is dependent on an effective separation of the steroid mixture into components by the paper chromatography. With extracts from most body fluids this can usually be achieved, but with occasional extracts of synovial fluid, impurities interfere with proper development.

Two trial recoveries from synovial fluid gave the following results:

Sample A: $26 \mathrm{ml}$. gave $2 \cdot 5 \mu \mathrm{g}$. hydrocortisone.

$26 \mathrm{ml}$. $+20 \mu \mathrm{g}$. hydrocortisone gave $12 \cdot 1 \mu \mathrm{g} .$, a recovery of 48 per cent

Sample B: $57 \mathrm{ml}$. gave $5 \cdot 1 \mu \mathrm{g}$. hydrocortisone. $57 \mathrm{ml}$. + $30 \mu \mathrm{g}$. hydrocortisone gave $30.4 \mu \mathrm{g}$., a recovery of 86 per cent.

The lower recovery in Sample A was associated with a poor chromatographic separation.

\section{Reagents}

(1) Blue Tetrazolium

(a) 1 per cent. solution in methanol of blue tetrazolium;

(b) $1 \mathrm{~N}$ sodium hydroxide in 80 per cent. aqueous methanol.

Equal volumes of these two solutions are mixed immediately before use.

(2) Acid Pyridine. 9 vols A.R. pyridine and 1 vol. A.R. hydrochloric acid are mixed and allowed to cool.

\section{Results}

Synovial fluid samples have been divided into two groups:

(a) those from patients who had received no steroid therapy in any form during the preceding 4 weeks;

(b) those from patients who were receiving regular steroid therapy at the time of aspiration of the knee fluid.

The results for the two groups are set out in Tables I and II.

TABLE I

HYDROCORTISONE CONTENT OF SYNOVIAL FLUID IN SUBJECTS NOT RECEIVING STEROID THERAPY

\begin{tabular}{|c|c|c|c|c|c|}
\hline $\begin{array}{c}\text { Sample } \\
\text { No. }\end{array}$ & Subject & $\begin{array}{l}\text { Volume } \\
\text { of Fluid }\end{array}$ & found & $\mu \mathrm{g}$ & Disease \\
\hline $\begin{array}{r}1 \\
2 \\
3 \\
4 \\
5 \\
6 \\
7 \\
8 \\
9 \\
10 \\
11 \\
12 \\
13\end{array}$ & $\begin{array}{c}\text { A } \\
\text { Pooled } \\
\text { Pooled } \\
\text { B } \\
\text { B } \\
\text { C } \\
\text { Pooled } \\
\text { D } \\
\text { Pooled } \\
\text { E } \\
\text { F } \\
\text { G } \\
\text { Pooled }\end{array}$ & $\begin{array}{r}45 \\
110 \\
130 \\
110 \\
145 \\
68 \\
77 \\
81 \\
96 \\
45 \\
39 \\
134 \\
96\end{array}$ & $\begin{array}{c}2 \cdot 5 \\
4 \cdot 9 \\
6 \cdot 3 \\
2 \cdot 4 \\
12 \cdot 6 \\
5 \cdot 4 \\
5 \cdot 2 \\
7 \cdot 5 \\
1 \cdot 06 \\
2 \cdot 2 \\
3 \cdot 75 \\
21 \cdot 2 \\
5 \cdot 9\end{array}$ & $\begin{array}{r}5 \cdot 0 \\
4 \cdot 5 \\
4 \cdot 9 \\
2 \cdot 2 \\
8 \cdot 7 \\
7 \cdot 9 \\
6 \cdot 8 \\
9 \cdot 3 \\
1 \cdot 1 \\
4 \cdot 9 \\
9 \cdot 6 \\
15 \cdot 8 \\
6 \cdot 1\end{array}$ & $\begin{array}{l}\text { Rheumatoid arthritis } \\
\text { Rheumatoid arthritis } \\
\text { Rheumatoid arthritis } \\
\text { Reiter's syndrome } \\
\text { Reiter's syndrome } \\
\text { Rheumatoid arthritis } \\
\text { Rheumatoid arthritis } \\
\text { Rheumatoid arthritis } \\
\text { Rheumatoid arthritis } \\
\text { Rheumatoid arthritis } \\
\text { Rheumatoid arthritis } \\
\text { Rheumatoid arthritis } \\
\text { Rheumatoid arthritis }\end{array}$ \\
\hline
\end{tabular}

Mean $6 \cdot 8 \mu \mathrm{g}$. per $100 \mathrm{ml} . \pm 3 \cdot 61$.

TABLE II

HYDROCORTISONE CONTENT OF SYNOVIAL FLUID IN RHEUMATOID ARTHRITIS SUBJECTS RECEIVING STEROID THERAPY

\begin{tabular}{c|c|c|c|c}
\hline $\begin{array}{c}\text { Sample } \\
\text { No. }\end{array}$ & Subject & $\begin{array}{c}\text { Volume } \\
\text { of Fluid }\end{array}$ & $\begin{array}{r}\mu \mathrm{\mu g} . \\
\text { found }\end{array}$ & $\begin{array}{r}\mu \mathrm{\mu g} . \\
\%\end{array}$ \\
\hline 14 & H & 50 & $4 \cdot 0$ & $8 \cdot 0$ \\
15 & H & 125 & $12 \cdot 0$ & $10 \cdot 0$ \\
16 & G & 82 & $1 \cdot 6$ & $2 \cdot 0$ \\
17 & Pooled & 153 & $14 \cdot 2$ & $9 \cdot 3$ \\
18 & Pooled & 98 & $9 \cdot 4$ & $9 \cdot 6$ \\
19 & H & 43 & $4 \cdot 1$ & $9 \cdot 5$ \\
20 & F & 35 & $4 \cdot 4$ & $12 \cdot 5$ \\
21 & G & 60 & $4 \cdot 8$ & $8 \cdot 0$ \\
22 & E & 45 & $4 \cdot 4$ & $9 \cdot 8$ \\
\hline
\end{tabular}

Mean $8 \cdot 7 \mu \mathrm{g}$. per $100 \mathrm{ml} . \pm 2 \cdot 69$.

(a) The mean of thirteen synovial fluid samples from subjects receiving no steroid was $6.8 \mu \mathrm{g}$. per $100 \mathrm{ml}$. (standard deviation $\pm 3 \cdot 61$ ).

(b) The mean of nine results of fluids from persons receiving steroid therapy was $8.7 \mu \mathrm{g}$. per $100 \mathrm{ml}$. (standard deviation $\pm 2 \cdot 69$ ). Most of the joint fluid samples in this group were from persons receiving oral cortisone in amounts greater than $50 \mathrm{mg}$. daily, but Sample 17 consisted of pooled fluids from several joints which had received intraarticular hydrocortisone 2 weeks previously.

Although the mean for the group receiving steroid therapy is higher than the mean from persons 
not given steroid, the difference between the two is little more than half one standard deviation. It is suggestive, but cannot be regarded as of real significance.

The mean and also the range of values found in the no steroid group is similar to that found in circulating blood. Our own figures for the blood hydrocortisone content, analysed by essentially the same method as has been used here for synovial fluids, are relatively few, but they range from mere traces up to $15 \mu \mathrm{g}$. per $100 \mathrm{ml}$. (mean 5.8 $\mu \mathrm{g}$.).

In some instances successive joint fluid samples were taken from the same patient.

Sample 4 (Table I) was aspirated 4 days after Sample 3 from the same joint of a patient suffering from Reiter's syndrome. Both samples were analysed in an identical manner and the divergent values afford a good example of the wide range of concentration which may occur in a single joint. In this case the first sample was removed from a very tense joint and its low hydrocortisone content may have been due to an interference with free circulation through the joint by the high intra-articular pressure.

Sample 21 was from the same joint as Sample 12. In this instance the hydrocortisone content was actually lower on oral cortisone therapy.

Sample 11 was from the same joint as Sample 20. Here the use of oral cortisone was associated with a higher synovial hydrocortisone concentration.

\section{Discussion}

The results indicate that a steroid with many of the properties of hydrocortisone, and believed in fact to be that steroid, is naturally present in the synovial fluid of rheumatoid arthritic knees with large effusion. The three properties we have used to identify the hydrocortisone spot (reducing power, opacity to ultraviolet light, and proper rate of flow in the chromatogram) are not of themselves sufficient to identify the steroid appearing in the spot as true hydrocortisone. We have previously shown, however, that the spot so designated, when derived from other body fluids such as the ascitic or pleural fluid, holds a steroid having many further properties in common with hydrocortisone. Thus it has been eluted with methanol, acetylated, and then found to run on a chromatogram at the same rate as authentic hydrocortisone acetate. The eluted steroid from this spot has also been shown by us to reduce the circulating eosinophils of the adrenalectomized mouse, an effect peculiar to cortisone and hydrocortisone. We have also found that it produces a colour with the Dische reagent (Clark, 1955) which has an absorption curve identical with that given by authentic hydrocortisone and widely different from that given by many closely allied steroids. Although a non-reducing steroid having strong ultraviolet opacity may sometimes occur at this spot on the chromatogram, the evidence suggests that the only reducing steroid present in this zone is hydro- ? cortisone. When large volumes of human ascitic $\vec{F}$ fluid are extracted by the same method as used here for synovial fluid and are treated in the same manner, the amount of reducing steroid appearing at this spot corresponds with the estimated hydrocortisone content of the ascitic fluid as judged by bioassay on the adrenalectomized mouse (Cope and Hurlock, कs 1953). It seems justifiable to conclude therefore $\vec{\circ}$ that the whole of the reducing steroid appearing at the hydrocortisone spot on chromatograms of $\vec{\omega}$ synovial fluid extracts is also hydrocortisone without other reducing steroid contaminant.

The range of hydrocortisone concentrations $\overrightarrow{\vec{A}}$ found by us in joint fluids is the same as that found by us in random samples of blood (Cope, Hurlock, $\omega$ and Sewell, 1955). Our own figures for blood are ${ }^{N}$ relatively few, but other information on the true 5 hydrocortisone content of blood is very scanty. $\overrightarrow{\vec{r}}$ There is no doubt that wide fluctuations occur. $\mathbb{D}$ Some indirect evidence exists, however, on which an $\mathbb{\Phi}$ estimate of mean hydrocortisone levels may be based. Bliss, Sandberg, Nelson, and Eik-Nes (1953)Ф have used a micro-method for estimating the plasnga $\overrightarrow{0}$ content of 17-hydroxy-corticosteroids, a group gf steroids having in common the ability to produese a yellow colour with phenylhydrazine in sulphupico acid. Hydrocortisone gives this colour, but unfortunately one or two inert metabolites of cortisone which are present in blood give it also. Estimates? based on this reaction tend therefore to be too high, but they do set an upper limit to the amount of hydrocortisone present. There are wide diurnal and other fluctuations, but these authors found a range of 3 to $26 \mu \mathrm{g}$. 17-hydroxy-corticosteroids (mean $13 \mu \mathrm{g}$.) per $100 \mathrm{ml}$. blood. Bayliss and Steinbeck (1953), using a modification of the same method: found a mean of $9.5 \mu \mathrm{g}$. per $100 \mathrm{ml}$. in normaB blood. These workers estimated that half of the chromogenic steroid present was hydrocortisone Their own results would therefore indicate a probable mean hydrocortisone content of $4.8 \mu \mathrm{g}$. pe? cent., whilst the figures of Bliss and his colleagues would similarly suggest an actual hydrocortisone content of about $6 \cdot 5 \mu \mathrm{g}$. per $100 \mathrm{ml}$. blood. Theses estimates thus agree well with our own findings in joint fluids.

Since our own data indicate therefore that the hydrocortisone content of the synovial fluid is usually maintained at a level comparable to that found in the blood, it may be concluded that diffio culty of access of hydrocortisone to the joint cavity 
is an infrequent occurrence and is unlikely therefore to be a regular factor in the aetiology of the rheumatoid arthritic process.

Very little work has yet been done on the hydrocortisone content of synovial fluids although several observers have studied the fate of hydrocortisone after injection of very large amounts into the joint space. One such group was Wilson, Glyn, Scull, McEwen, and Ziff (1953), who observed in a single specimen of synovial fluid from a patient receiving oral cortisone acetate alone, a faint band having a mobility similar to that of hydrocortisone. More recently McEwen, Wilson, and Ziff (1954) have stated their experience that extracts of amounts of synovial fluid as large as $130 \mathrm{ml}$. chromatographed on very narrow papers have yielded either no bands or extremely faint ones. We believe that this pronounced difference in results between ourselves and the latter workers is probably due to minor differences of technique. We have discarded narrow strips for the paper chromatography in favour of strips sufficiently wide to prevent any steroid spreading to the edge of the paper. We find that much greater sensitivity is obtained in this way, and spots of hydrocortisone containing as little as $2 \mu \mathrm{g}$. can be recognized. Such sensitivity has not been possible on narrow strips which are also more difficult to handle.

Although hydrocortisone spots are regularly seen, we have never been able to detect cortisone in joint fluids even in subjects who were receiving it orally. When cortisone or cortisone acetate is ingested, some of it is rapidly converted into hydrocortisone (probably by the liver), and this soon appears in the urine. Cope and Hurlock (1954) found that, after cortisone ingestion, approximately equal amounts of hydrocortisone and of cortisone appeared in the urine. Some hydrocortisone probably enters the synovial fluid, but apparently no cortisone does so.

Evidence is accumulating from other workers that a rapid interchange of steroid occurs in rheumatoid joints. Wilson, Glyn, Scull, McEwen, and Ziff (1953) injected 50-mg. doses of cortisone and of hydrocortisone intra-articularly and found a very rapid disappearance of the steroid from the joint space. In one hour about 85 per cent. had disappeared and in 3 hours 98 per cent. The therapeutic doses injected were very greatly in excess of the naturally occurring quantities, and it is probable that much of this injected steroid was treated as a foreign body. Evidence suggesting this has been obtained by Hollander (1953) who found unchanged cortisone acetate or hydrocortisone acetate within the cells of the synovial fluid after intra-articular injection, and these observations have been extended by
Zacco, Richardson, Crittenden, Hollander, and Dohan (1954). But Gallagher (1954) injected radioactive cortisone into a rheumatoid arthritis effusion and was able to show that it disappeared rapidly and at a rate similar to that of injected radiosodium. Although only scanty details are given, it seems certain that the actual amounts injected were much nearer the natural levels. It must be concluded, therefore, that a continual and fairly rapid interchange of steroid is occurring in the rheumatoid joint.

Hydrocortisone is by no means the only steroid present. Wilson, Glyn, Scull, and McEwen (1953) have noted the rapid appearance of metabolites of hydrocortisone in joint fluids after injection of the steroid. We have frequently, but not invariably, found small amounts of two reducing steroids having properties suggestive of tetra-hydro-cortisone and of tetra-hydro-hydrocortisone respectively, in joint fluids from persons who have received no steroid therapy. These steroids react with the reagent of Porter and Silber (1950); the apparent hydrocortisone content is considerably increased if this reagent is used for analysis of extracts not purified by chromatography. The amounts of these metabolites present may be greater than the amount of hydrocortisone itself. Both metabolites are physiologically inert, and it may be presumed that they also are promptly removed from the joint space as they are formed.

\section{Summary}

A substance having properties similar to hydrocortisone can be regularly detected in synovial fluid from the knees of patients with rheumatoid arthritis. Reasons are given for believing that this is true hydrocortisone.

Quantitative estimation of this substance gave a mean concentration of $6.8 \pm 3.6 \mu \mathrm{g}$. per $100 \mathrm{ml}$. in thirteen samples.

The mean concentration in nine joint fluids from subjects receiving oral cortisone therapy was $8 \cdot 7 \pm$ $2 \cdot 7 \mu$ g. per $100 \mathrm{ml}$.

The difference between the two groups is not significant.

The mean concentration in joints is similar to the mean concentration found in blood.

It is concluded that difficulty of access of natural hydrocortisone to the joint cavity is not an important aetiological factor in rheumatoid arthritis.

Our gratitude is due to many members of the Rheumatology Service of the Hammersmith Hospital for providing the samples of synovial fluid. 
Bayliss, R. I. S., and Steinbeck, A. W. (1953). Biochem. J., 54, 523. Bliss, E. L., Sandberg, A. A., Nelson, D. H., and Eik-Nes, K. (1953). J. clin. Invest., 32, 818

Burton, R. B., Zaffaroni. A., and Keutmann, E. H. (1951). J. biol. Chem., 188, 763 .

Clark, I. (1955). Nature (Lond.), 175, 123.

Cope, C. L., and Hurlock, B. (1953). Brit. med. J., 2, 753.

- (1954). Clin. Sci., 13, 69

Gallagher, T. F. (1954). In "Trans. 5th Conf. Adrenal Cortex", p. 45. Josiah Macy, Jr., Foundation. New York.

Hollander, J. L. (1953). Annals of the Rheumatic Diseases, 12, 347. McEwen, C., Wilson, H., and Ziff, M. (1954). Trans. Ass. Amer. Phys., 67, 97.

Porter, C. C., and Silber, R. H. (1950). J. biol. Chem., 185, 201.

Wilson, H., Glyn, J., Scull, E., McEwen, C., and Ziff, M. (1953). Proc. Soc. exp. Biol. (N.Y.), 83, 648 .

Zacco, M., Richardson, E. M.. Crittenden, J. O., Hollander, J. L., and Dohan, F. C. (1954). J. clin. Endocr., 14, 711.

\section{Présence d'hydrocortisone naturelle dans le liquide synovial}

\section{RÉSUMÉ}

On peut décéler normalement une substance ayant des propriétés d'hydrocortisone dans le liquide synovial du genou des arthritiques rhumatismaux. On donne des raisons pour croire qu'il s'agit de l'hydrocortisone même.

La détermination quantitative de cette substance dans treize échantillons donne un chiffre moyen de $6,8+$ 3,6 $\mu \mathrm{g}$. par 100 c.c.

Le chiffre moyen pour neuf liquides synoviaux pro- venant des sujets recevant de la cortisone par voie buccale est de $8,7 \pm 2,7 \mu \mathrm{g}$. par 100 c.c.

La différence entre ces deux groupes n'est pas significative.

Le taux moyen articulaire est similaire au taux moyen sanguin.

On en conclut qu'une difficulté d'accès de l'hydrocortisone à la cavité articulaire n'est pas un facteur étiologique important dans l'arthrite rhumatismale.

\section{Presencia de hidrocortisona natural en el líquido sinovial \\ SUMARIO}

Una substancia con propiedades de hidrocortisona se puede encontrar normalmente en el líquido sinovial $\vec{\circ}$ de las rodillas de enfermos con artritis reumatoide. Se dan aquí razones para creer que se trata de la hidro- $\vec{\omega}$ cortisona misma.

La determinación cuantitativa de esta substancia en trece espécimenes dió la cifra media de $6,8 \pm 3,6 \mu \mathrm{g}$. por 100 c.c.

La cifra media para nueve líquidos sinoviales de sujetos tratados con cortisona por vía oral fué de 8,7 $2,7 \mu$ g. por 100 c.c.

La diferencia entre estos dos grupos no es significativa.

La cifra media articular y la cifra media sanguínea son similares.

Se concluye que una dificultad de acceso de la hidro- $\square$ cortisona a la cavidad articular no constituye un factor $\mathbb{D}$ etiológico importante en la artritis reumatoide. 